Relations industrielles

Industrial Relations

\title{
Labor Relations, by Arthur A. Sloane et Fred Witney, Prentice Hall Inc., Englewood Cliffs, N.J., 1967, 450 pages.
}

Jean Sexton

Volume 22, numéro 3, 1967

URI : https://id.erudit.org/iderudit/027822ar

DOI : https://doi.org/10.7202/027822ar

Aller au sommaire du numéro

Éditeur(s)

Département des relations industrielles de l'Université Laval

ISSN

0034-379X (imprimé)

1703-8138 (numérique)

Découvrir la revue

Citer ce compte rendu

Sexton, J. (1967). Compte rendu de [Labor Relations, by Arthur A. Sloane et Fred Witney, Prentice Hall Inc., Englewood Cliffs, N.J., 1967, 450 pages.] Relations industrielles / Industrial Relations, 22(3), 452-453.

https://doi.org/10.7202/027822ar

Tous droits réservés @ C Département des relations industrielles de l'Université Laval, 1967
Ce document est protégé par la loi sur le droit d'auteur. L'utilisation des services d'Érudit (y compris la reproduction) est assujettie à sa politique d'utilisation que vous pouvez consulter en ligne.

https://apropos.erudit.org/fr/usagers/politique-dutilisation/ 
This book is meant to awaken motivotion obout a variety of labor problems, by its use as a supplement to a textbook in college courses or as the basis for discussion in cdult programs where the participants already have some understanding of labor and industrial relations.

The problems of unemployment, minority welfare, leisure and automation are not more related to union activity than they are to the conduct of others institutionsemployees, schools, civic groups, and political parties, for example. These labor issues need to be presented in their own right-not just in their relation to the organized sector of the labor force. Three chapters, - unemployment, the disadvantaged, work and leisure - provide this kind of presentation. They are in Part one: "The Broad Contexty

Part Two: \&abor's Involvement include six chapters - Is there still a labor Movement? Must Union Membership Decline? Inside the Unions Innovations in Collective Bargaining, the Role of Government in Industriol Relations, Labor and Politics - which are oriented largely, though not completely, oround organized lobor.

Several chapters in each part are divided into sections so that the reader may easily grosp the major issues that are covered.

\section{Pierre DIONNE}

\section{Days of Our Years with Labor,par Robert C. Knee, The W.H. Anderson Company, Cincinnati, 1966, 160 pages.}

Essentiellement, ce livre est une histoire concise du développement du droit du trovoil en Amérique depuis ses débuts. Malgré I'impossibilité de trancher au couteau les trois grandes phases de croissance du droit du trovoil, à sovoir l'ère de la conspiration criminelle, l'ère des injonctions et l'ère interventionniste, l'auteur essaie quand même d'identifier chacune d'elles dans l'histoire des Etats-Unis. Pour refaire, il part de la période pré-révolution civile pour aboutir à la Loi sur les heures de travail de 1962, en passant évidemment par les fameuses lois Wogner, Thaft Hortley, Landum Griffin et Norris Lo Guordio.

Chose remarquable à noter quant à la méthode utilisée, l'auteur se fait un devoir de toujours expliquer le contexte historique qui o entouré l'adoption de chacune des lois influençont le syndicot et l'employeur.

\section{Jean SEXTON}

Labor Relations, by Arthur A. Sloane et Fred Witney, Prentice Hall Iric., Englewood Cliffs, N.J., 1967, 450 poges.

A unified treatment of the labor-manogement field, focusing on collective bargaining, with emphasis on the development and application of today's vital bargaining issues, together with ten orbitration cases to present a practical application of theories, this is Labor Relations.

By means of description, analysis, discussion questions and arbitration cases drawn from the author's own experiences, this book describes all basic phases of labor relations and how they offect the business man.

The direction which this book will take is an obvious one: downward from a brood overview of the general noture of the lobormanagement relationship as it currently exists in the United States (Port 1), through a survey of the historical, legal and structural environments which so greatly influence contractuol contents and labor relation, behovior (Part 2), to a close examination of the negotiation, administration, and major contents of the labor contract itself (Part 3)

Let us reconsider each part separately. In part one, the authors set the stage by explaining the stote of the unions todoy, the reasons for workers to join unions, for manager to resist them, and the management philosophies toword unions.

In part two Sloane and Witney describe the historical framework from the eighteenth century, to the AFL-CIO reality. The outhors also explain in this port both the legol framework, from the era of judiciol control to the Landum Griffin and the union structure, government and operation.

Finally, the main part of this book is dedicated to the collective bargaining; the preparation for negotiations, the bargaining process, the administration of the agreement, the wage issues, the economic supplements, the institutional and administrative issues of collective bargaining.

We could resume the content of this book by describing some of its highlights: 
1.-Labor Relations is illustrated with ten carrefully selected arbitration coses.

2. - This book is a depth study of the behovioral phases of labor relations.

3.-It emphasizes the vital issues of collective bargoining.

4.-Labor Relations considers the impact of technology, growth of white-collar employment and worker motivation.

5.--Labor Relations contains a detailed mock negotiation problem

In concluding, let us say that this book is a very interesting study of the labor relotions reality and a practical and comprehensive approach to the negotiation and administration of today's labor-management issues.

\section{Jean SEXTON}

Manpower Planning in a Free Society, by Richard A. Lester, Princeton University Press, Published by Saunders of Toronto Ltd, 1966, 22 pages.

While in the fifties the main preoccupation in industrial relations was unionmanagement relations, today the spotlight has shifted to another areo which tended until recently to be neglected, manpower policy.

The central theme of this book is that the hand of government can and should be used more constructively to facilitate effective utilization of manpower. The role of government should not be to control on direct manpower but rather to moke it easier for individuals to choose careers, to prepare themselves adequately and to change jobs

The author analyzes the need for manpower planning, the nature of such planning and the ways that it could improve the functionning of our mixed economy.

Mr. Lester's recommandations include:

1.-exponding reseorch and analysis to give more depth to the Annual Manpower Reports of the President.

2.-extending the functions of the Federal State Employment Service including the establishment of a national cleoring center for high tolent manpower. 3.-improving programs of information and training to enlarge opportunities at all levels, enabling men and women to realize more fully their potentiol earning power and economic contribution.

In addition to these recommandations this book urges that more stress be placed on knowledge-generating research and on the distribution of useful information about monpower needs and opportunities. Manpower Planing in a Free Society sets forth a pattern of thought and a program of action.

\section{Jean SEXTON}

Information and Economic Progress, Howard R. Bowen and Garth L. Mangum, Editors, 170 p. $\$ 4.95$, Clothbound $/ \$ 1.95$ poper, Prentice-Hall Inc., 1967.

The editors of this volume are Dr. Howard $R$. Bowen, president of the University of lowa and Garth L. Mangum. Dr. Bowen was chairman and Dr. Mangum executive secretary of the National Commission on Technology, Automation, and Economic Progress, whose report was filed in 1966. The Commission was appointed by President Johnson pursuant to an act of the Congress of the United States. Its distinguished membership ambraced leaders in management, labor and ocodemic and public life.

The reviewer had occasion to offer a critiaue of the findings of the Commission in Personnel Journal, April, 1966 issue.

The book contains a condensation of the text of the Commission's report, together with selections from the six published volumes of supplementary studies which contain much source material for the report.

Since the report, itself, is divided into various chapters and considers more than 40 topics, only highlight references can be made here. Serious students of the industrial scene will from a careful examination of its content and the Commission views on these various subjects.

Some of the proposals of the Commission have never been advanced by any official bodies in the United States. These included a guaranteed minimum maintenance of income provision, reverse tox benefits, the ossumption of a governmental obligation to employ the hard core jobless, and the great expenditure of public moneys for the accomplishment of these social purposes. 